\title{
Dynein Light Chain Roadblock-Type 1
}

National Cancer Institute

\section{Source}

National Cancer Institute. Dynein Light Chain Roadblock-Type 1. NCI Thesaurus. Code C98175.

Dynein light chain roadblock-type 1 ( $96 \mathrm{aa}, \sim 11 \mathrm{kDa}$ ) is encoded by the human DYNLRB1 gene. This protein plays a role in the progression of microtubule-dependent intracellular transport. 